\title{
Programmed cell death-1 (PD-1) at the heart of heterologous prime-boost vaccines and regulation of $\mathrm{CD}^{+} \mathrm{T}$ cell immunity
}

\author{
Adrian Bot* , Zhiyong Qiu, Raymond Wong, Mihail Obrocea, Kent A Smith
}

\begin{abstract}
Developing new vaccination strategies and optimizing current vaccines through heterologous prime-boost carries the promise of integrating the benefits of different yet synergistic vectors. It has been widely thought that the increased immunity afforded by heterologous prime-boost vaccination is mainly due to the minimization of immune responses to the carrier vectors, which allows a progressive build up of immunity against defined epitopes and the subsequent induction of broader immune responses against pathogens. Focusing on $\mathrm{CD}^{+} \mathrm{T}$ cells, we put forward a different yet complementary hypothesis based primarily on the systematic analysis of DNA vaccines as priming agents. This hypothesis relies on the finding that during the initiation of immune response, acquisition of co-inhibitory receptors such as programmed cell death-1 (PD-1) is determined by the pattern of antigen exposure in conjunction with Toll-like receptor (TLR)-dependent stimulation, critically affecting the magnitude and profile of secondary immunity. This hypothesis, based upon the acquisition and co-regulation of pivotal inhibitory receptors by $\mathrm{CD}^{+} \mathrm{T}$ cells, offers a rationale for gene-based immunization as an effective priming strategy and, in addition, outlines a new dimension to immune homeostasis during immune reaction to pathogens. Finally, this model implies that new and optimized immunization approaches for cancer and certain viral infections must induce highly efficacious $T$ cells, refractory to a broad range of immune-inhibiting mechanisms, rather than solely or primarily focusing on the generation of large pools of vaccine-specific lymphocytes.
\end{abstract}

\section{The 'magic' of heterologous prime-boost vaccination}

Vaccines are arguably the best medical tools we have at our disposal to fight widespread infectious diseases. Despite decades of vaccine research and development against life-threatening infectious diseases with global impact [1], culminating with the recent licensing of vaccines against human papillomaviruses (HPV) [2], a key cause of cervical cancer, successes have been confined primarily to prophylaxis. Vaccination has also been extensively researched for the prevention of HIV infection. Therapeutic immunization for cancer or chronic viral infection, however, brings in a new set of lessons and challenges with a few successes to date, such as treatment of HPV-related lesions [3]. It became rapidly evident that the conventional paradigm of eliciting, amplifying, and maintaining immune

\footnotetext{
* Correspondence: abot@mannkindcorp.com

MannKind Corporation, 28903 North Avenue Paine, Valencia, CA 91355. USA
}

responses with conventional vectors and homologous prime-boost approaches fell short of expectations in the clinic due to suboptimal immune response results. Two decades since the first cloning of tumor antigens [4], multiple vaccines are currently in development. Thus far, however, sipuleucel $\mathrm{T}$ (Provenge ${ }^{\circ}$ ) is the only approved therapeutic cancer vaccine in the US to date, consisting of autologous DCs expressing prostate acid phosphatase (PAP) and producing granulocyte macrophage colony-stimulating factor (GM-CSF) to treat hormone-refractory prostate cancer [5].

The HIV vaccine field has unquestionably been at the forefront of vaccine research, exploring potent immunization strategies comprised of synthetic vectors rather than cell-based vaccines. This is in contrast to efforts in cancer vaccine development where cell-based vaccines currently lead the field, while many synthetic and viral vector approaches are in clinical development $[6,7]$. Nevertheless, homologous prime-boost approaches for the prophylaxis of HIV, such as the Vaxgene program,

\section{()


showed no significant protective effects in man [8]. While in parallel, emerging evidence over the last two decades showed that novel prime-boost protocols integrating different vectors such as recombinant viruses and proteins $[9,10]$ did yield considerably higher immune responses with protective capability in several animal models. With the advent of other vectors such as DNA vaccines, and a range of recombinant microbial vectors including alpha virus replicons, research in the area of heterologous prime-boost vaccination against HIV has expanded and resulted in hundreds of preclinical and clinical studies. Interestingly, the most promising clinical regimens to date include: i) the RV144 landmark HIV 'Thai trial' which utilized recombinant viral priming followed by a protein boost and was the first to show modest yet statistically significant evidence of HIV vaccine efficacy in man [10]; ii) DNA priming coupled with protein [11]; or iii) DNA priming followed by a recombinant virus boost [12].

Significant evidence points to two major reasons why heterologous prime-boost vaccination is a more promising strategy compared to homologous prime-boosting: i) diminished anti-vector antibody responses [13] known to interfere with immunity against target epitopes through the clearance and degradation of vaccine via vaccine-antibody immune complexes; and ii) there is the potential for different vectors to work synergistically by inducing complementary arms of the immune response to jointly control complex pathogenic processes and overcome immune escape mechanisms. For example, while recombinant proteins are quite effective at inducing $B$ and Th immunity, viral vectors can be more effective at inducing cytotoxic $\mathrm{T}$ cells [14].

DNA vaccine vectors offer several advantages, including the potential to elicit MHC class I-restricted immunity, reduced induction of anti-vector antibody responses, and reliance on a simple manufacturing process [15]. Nevertheless, DNA vaccination alone has yielded disappointing results in numerous clinical trials due to modest immune responses [16]. These results were largely attributed to low levels of vector-encoded antigen, resulting in low numbers of APCs expressing target epitopes, and subsequent inferior $\mathrm{T}$ cell stimulation and expansion in vivo [17]. Furthermore, intra-dermal gene-gun delivery [18], intra-lymphatic administration $[19,20]$, or other enhancing approaches such as electroporation [21], have only partially improved the immune response achievable by DNA vaccination alone. Nevertheless, the potential of immune priming without the generation of interfering anti-vector antibodies has positioned DNA vaccines (Figure 1) as a primary component of several heterologous prime-boost vaccines in development for the treatment of diseases such as HIV, other microbes and cancer [11,22-37]. In addition, such protocols offer a more practical alternative for active immunotherapy of cancer and other diseases since they rely on synthetic or 'off the shelf' vectors, as compared to personalized DC-based vaccines [38].

The optimal positioning of current and future DNA vectors within innovative heterologous prime-boost immunization regimens requires a deeper understanding of the mechanism of action of DNA vaccination. A key observation from many studies to date is that interchanging the order of vectors utilized in these regimens has a dramatic impact on the resulting immune response. For example, while DNA priming followed by a virus boost resulted in significant epitope-specific responses, viral priming followed by DNA boost failed to reproduce this level of specific immunity [39]. A similar result was observed with other vectors in a distinct model, clearly supporting a precise sequence of administration of vectors as a major factor determining the magnitude of immunity [40], although this hypothesis still requires further testing in other heterologous prime-boost vaccine protocols. This asymmetry between priming and boosting vectors could very well be at the heart of both the mechanism and advantage of heterologous primeboost regimens. Therefore, the remainder of this review will focus on this key feature and its underlying mechanism, with emphasis on DNA vaccines as priming agents and $\mathrm{CD}^{+} \mathrm{T}$ cell immunity as the desired outcome, as it pertains to the control of cancer and chronic viral infections. Moreover, although we focus on the functionality of $\mathrm{CD}^{+} \mathrm{T}$ cells in this review, we recognize the importance of $\mathrm{CD} 4^{+} \mathrm{T}$ cells and the possibility that these cells may influence the outcome of vaccine protocols with respect to $\mathrm{PD}-1$ expression by $\mathrm{CD} 8^{+}$ $\mathrm{T}$ cells.

\section{PD-1 and co-inhibitory receptors: a new dimension to prime-boosting and immune regulation}

The fundamental concept behind heterologous primeboost vaccination is the synergistic contribution of two categories of vectors to induce enhanced immunity against given epitopes. To investigate the immune mechanisms underlying this process, we initiated a systematic evaluation utilizing a reductionist approach that encompasses simple vectors with well-defined MHC class I-restricted epitopes. Using a Melan A/MART-1 preclinical experimental model, we developed a strategy that greatly enhances the immune properties of nonreplicating vectors and biological response modifiers by direct intra-nodal administration of plasmid and peptide $[19,41]$. We showed that the sequence and the route of administration of plasmid and peptide were absolutely essential to achieve improved antigen-specific $\mathrm{CD} 8^{+}$ $\mathrm{T}$ cell immune responses [40]. While intra-lymph node 


\begin{tabular}{|c|c|c|c|}
\hline \multicolumn{2}{|c|}{ Boosting vectors } & \multirow[t]{2}{*}{ Results summary } & \multirow[t]{2}{*}{ References } \\
\hline $\begin{array}{l}\text { Vector } \\
\text { category }\end{array}$ & Targets / Formulations & & \\
\hline $\begin{array}{l}\text { Polypeptides } \\
\text { or recombinant } \\
\text { proteins }\end{array}$ & $\begin{array}{l}\text { Env of primary HIVs (subtypes A-E) } \\
\text { Hsp65-Gastrin releasing peptide } \\
\text { Melan A peptide }\end{array}$ & $\begin{array}{l}\text { Induction of neutralizing antibodies in rabbit } \\
\text { Antibody and anti-tumor effect in mouse } \\
\text { Induction of elevated T cell response }\end{array}$ & $\begin{array}{l}(22) \\
(23) \\
(40)\end{array}$ \\
\hline $\begin{array}{l}\text { Microbial } \\
\text { vectors }\end{array}$ & $\begin{array}{l}\text { Live influenza virus } \\
\text { BCG } \\
\text { Vaccinia (MVA) expressing HIV antigens } \\
\text { Fowlpox - expressing HIV antigens } \\
\text { Adenovirus - expressing HIV antigens } \\
\text { Adenovirus - expressing } \alpha \text {-fetoprotein } \\
\text { VSV - expressing Gag of HIV }\end{array}$ & $\begin{array}{l}\text { Induction of robust CTL immunity in mouse } \\
\text { Immunity against Hsp67, 70, Apa in calves } \\
\text { Protective immunity against SHIV in primates } \\
\text { Protective immunity against SHIV in primates } \\
\text { Protective immunity against SHIV in primates } \\
\text { Protective Th1 immunity in a mouse tumor model } \\
\text { Enhanced immunogenicity in primates }\end{array}$ & $\begin{array}{l}(24) \\
(25) \\
(26) \\
(27) \\
(28) \\
(29) \\
(30)\end{array}$ \\
\hline $\begin{array}{l}\text { Inactivated } \\
\text { viruses }\end{array}$ & $\begin{array}{l}\text { Inactivated rabies } \\
\text { Inactivated influenza }\end{array}$ & $\begin{array}{l}\text { Increased neutralizing immunity in mice, cattle } \\
\text { Increased neutralizing antibody levels in mouse }\end{array}$ & $\begin{array}{l}(31) \\
(32)\end{array}$ \\
\hline
\end{tabular}

\section{B. Clinical trials}

Boosting vectors

\begin{tabular}{|l|l|}
\hline Vector category & Targets / Formulations \\
\hline Proteins & Polyvalent HIV Env formulation* \\
\hline Microbial vectors & $\begin{array}{l}\text { Vaccinia (NYVAC) - HIV } \\
\text { Adenovirus expressing PSMA } \\
\text { Vaccinia (MVA) - melanoma epitopes } \\
\text { Vaccinia (MVA) - malaria TRAP }\end{array}$ \\
\hline
\end{tabular}

Multivalent humoral and polyfunctional cellular

Results summary immunity in healthy volunteers

DNA priming against Gag and multiple envelope proteins.

In blue: studies with cancer antigens.

Figure 1 Representative studies to date, evaluating DNA priming - heterologous boosting

priming with DNA (plasmid) and boosting with peptide afforded a robust expansion of epitope-specific $\mathrm{CD} 8^{+}$ $\mathrm{T}$ cells (on the order of $1 / 2-1 / 10$ specific $\mathrm{T}$ cells/total $\mathrm{CD} 8^{+} \mathrm{T}$ cells), reversing the order of the vectors resulted in a limited overall $\mathrm{T}$ cell expansion $(\sim 1 / 100-1 / 1000$ or less, of specific $\mathrm{T}$ cells/total $\mathrm{CD} 8^{+} \mathrm{T}$ cells) within the same range of homologous prime-boost vaccination [40]. A closer look at the immunity primed by plasmid showed that, in stark contrast to peptide priming, the epitopespecific $\mathrm{CD}^{+} \mathrm{T}$ cells, although few in numbers $(\sim 1 / 100$ specific/total $\mathrm{CD}^{+} \mathrm{T}$ cells), had some strikingly distinguishing features. Within the population of $\mathrm{CD} 8^{+} \mathrm{T}$ cells initiated by plasmid, we found a significant frequency of the lymphatic migration marker $\mathrm{CD}^{2} 2 \mathrm{~L}^{+}$(central/lymphoid-memory) epitope-specific $\mathrm{CD}^{+} \mathrm{T}$ cells with a limited capability to produce proinflammatory cytokines upon peptide stimulation ex vivo. Nevertheless, these DNA vaccine-primed cells showed long-term persistence in vivo and displayed a high expansion potential following in vivo or in vitro re-exposure to antigen, associated with a rapid loss of CD62L and a broadening of their functional capabilities [40].
This obviously raised the question: Does priming with a DNA vaccine result in $\mathrm{CD}^{+} \mathrm{T}$ cells that are more resilient to negative regulatory mechanisms that would otherwise impose restrictions on the expansion and activity of this key subset of $\mathrm{T}$ cells? To test our hypothesis, we compared the global gene expression in epitope-specific $\mathrm{CD} 8^{+} \mathrm{T}$ cells generated by vaccination against Melan A/MART-1 with plasmid versus peptide in mouse [42]. We found numerous differences in regards to the transcriptome, most notably at the level of expression of genes encoding inhibitory receptors (Figure 2). More specifically, PD-1, CTLA-4, Lag-3 and the prostaglandin receptor Ptger2 were all significantly up-regulated in antigen-specific $\mathrm{CD}^{+} \mathrm{T}$ cells from peptide (but not DNA) immunized mice, with the latter retaining a more 'naïve-like' phenotype from this point of view. In contrast, a member of the Klr family controlling the natural killer activity of lymphocytes was vastly down-regulated in $\mathrm{CD}^{+} \mathrm{T}$ cells primed with peptide. Previous evidence also suggested that DNA vaccination elicited specific $\mathrm{T}$ cells with low $\mathrm{PD}-1$ expression levels $[43,44]$. 


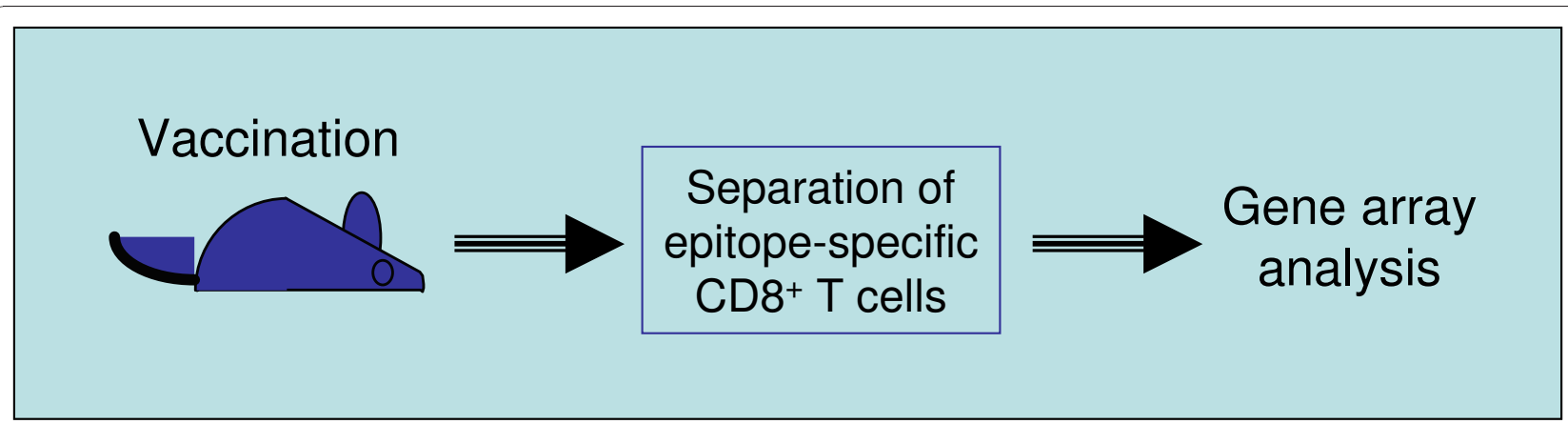
Summary of transcriptome analysis by gene array applied to Melan A / MART-1 epitope
specific CD8 ${ }^{+}$T cells

\begin{tabular}{|l|c|c|c|c|}
\hline \multicolumn{1}{|c|}{ Gene Symbol } & \multicolumn{2}{c|}{$\begin{array}{c}c \mid \\
\text { (DNA-primed change }\end{array}$} & \multicolumn{2}{c|}{$\begin{array}{c}\text { Fold change } \\
\text { (DN control) }\end{array}$} \\
(Peptide-primed vs control)
\end{tabular}

Figure 2 Differential co-expression of inhibitory receptors by $\mathrm{CD}^{+} \mathrm{T}$ cells depending on priming. In brief, epitope-specific $T$ cells from immunized mice were highly purified and analyzed without additional stimulation. Gene expression patterns were defined using hierarchical clustering; $C D 8^{+} T$ cells from naive mice were used as a reference control. The bottom half of the figure summarizes the results pertaining to expression of inhibitory receptors such as PD-1, as average fold change of gene expression relative to control. There was coordinated upregulation of gene expression corresponding to membrane receptors with inhibitory activity (yellow shaded section: Lag3, CTLA-4 and PD-1) in $\mathrm{CD} 8^{+} \mathrm{T}$ cells primed by peptide without adjuvant, but not DNA vaccine (summary of results in ref. [42]).

This tandem co-regulation of inhibitory receptors [45-47] raised the possibility that this phenomenon, consisting of the generation of specific $\mathrm{T}$ cells that fail to up-regulate PD-1, extends beyond DNA vaccination. We investigated this concept by utilizing the opportunity afforded by intra-lymph node administration to evaluate the immune profile of peptide epitopes and biological response modifiers in their simplest form. Intriguingly, a rather low dose of peptide co-administered with robust doses of CpG (TLR9 ligand) resulted in Melan A/MART-1-specific $\mathrm{CD}^{+} \mathrm{T}$ cells with low PD-1 expression levels [48], reproducing essentially the profile achieved by DNA vaccination (Figure 2). In stark contrast, a peptide dose increase or CpG dose reduction yielded increased levels of $\mathrm{PD}-1$ expression on specific $\mathrm{CD}^{+} \mathrm{T}$ cells. The induction of $\mathrm{T}$ cells with a high PD-1 expression level by peptide immunization alone may be due to co-presentation by professional and non-professional APCs alike. Co-administration of
TLR ligands (such as CpG motifs and others) are expected to activate of APCs resulting in a favorable PD-1 profile [49-51]. As far as we know, the molecular mechanisms for these findings remain to be elucidated. Complementing these results, ex vivo antigen restimulation with simultaneous anti-PD-1 blockade restored the proliferation of $\mathrm{PD}-1^{\text {high }} \mathrm{CD}^{+} \mathrm{T}$ cells isolated from mice immunized with peptide only to levels similar to that of $\mathrm{T}$ cells from mice immunized with peptide + CpG or plasmid alone (Figure 3). This result strongly supports the functional relevance of this coinhibitory molecule as a major regulator of $\mathrm{CD}^{+}$ $\mathrm{T}$ cell activity in the context of DNA priming- heterologous boosting and beyond. Furthermore, this nicely complements previous observations obtained with OVA-specific $\mathrm{CD}^{+} \mathrm{T}$ cells defective in PD-1 expression in an autoimmune setting, showing the pivotal negative regulatory role of PD-1 both at the level of $\mathrm{T}$ cell expansion as well as during in situ activity [52]. 


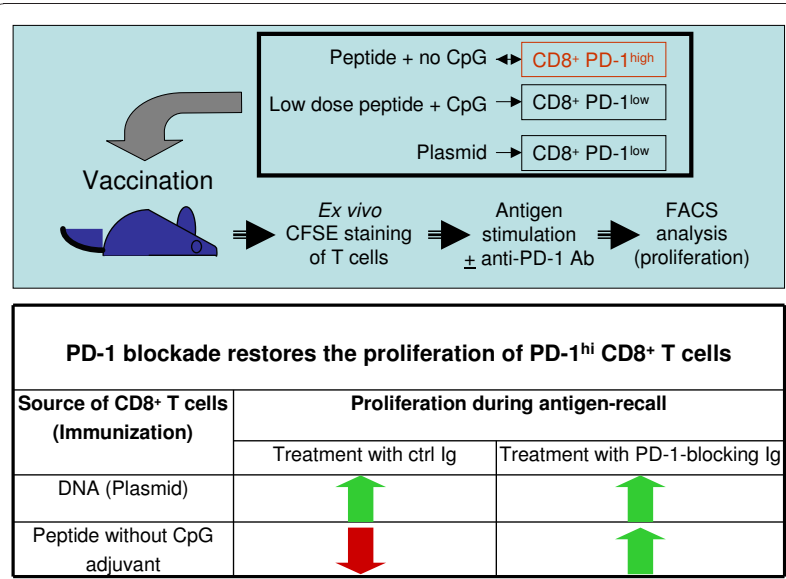

Figure 3 The responsiveness of $\mathrm{CD}^{+} \mathrm{T}$ cells is "imprinted" during the priming phase through PD-1 acquisition. The upper panel depicts the general methodology: mice were immunized by various regimens and specific $T$ cells were restimulated ex vivo with HLA-A*0201-binding human Melan A 26-35 native peptide (EAAGIGILTV), in the presence of PD-1 blocking antibodies or control immunoglobulin. Ex vivo T cell proliferation was measured using a standard CFSE staining assay. The bottom panel depicts a summary of the results comparing the essential groups: T cells from Melan A plasmid versus Melan A 26-35 analogue peptide (ELAGIGILTV) immunized mice. While the epitope-specific T cells from DNA vaccinated mice had low PD-1 expression and high proliferative potential persistently, the T cells from peptide immunized mice had high PD-1 expression and low proliferative potential; however, their proliferation could be easily restored through blocking PD-1/PD-1L interaction, speaking to the critical role of PD-1 in determining the fate of $C D 8^{+} T$ cells post-priming (summary of results in refs. [42] and [48]).

In this experimental setting, PD-1 $1^{-/-}$OVA-specific $\mathrm{T}$ cells were adoptively transferred into transgenic mice expressing the antigen under the rat insulin promoter. The $\mathrm{PD}-1^{-1-} \mathrm{T}$ cells proliferated to a higher extent in draining lymph nodes and caused insulitis and diabetes, in dramatic contrast to wild-type PD-1competent $\mathrm{T}$ cells which were unable to mediate a similar outcome.

With regard to the basic mechanisms of DNA priming/heterologous boosting, the following model thus emerges (Figure 4). Effective priming agents such as DNA vaccines induce a population of antigen-specific $\mathrm{T}$ cells with a central-memory phenotype $\left(\mathrm{CD} 6 \mathrm{~L}^{+}\right)$that reside within lymphoid organs and manifest a reduced expression of inhibitory receptors such as PD-1, CTLA4 and LAG-3, rendering them relatively impervious to a range of negative regulatory mechanisms. In addition, they exhibit a subtle cytokine expression potential and yet have a great capacity for persistence, expansion and differentiation. Boosting agents such as peptides, if delivered to achieve optimal exposure and TCR-dependent stimulation, can then rapidly drive the expansion and differentiation of DNA-primed $\mathrm{CD}^{+} \mathrm{T}$ cells to peripheral memory/effector cells $\left(\mathrm{CD} 2 \mathrm{~L}^{\mathrm{neg}}\right)$ that are no longer confined to the lymphatic system and are able to survey peripheral organs. These differentiated cells, nevertheless, simultaneously acquire expression of inhibitory receptors such as PD-1 and are therefore far more susceptible to negative regulatory mechanisms in vivo. While boosting would effectively result in activated cells endowed with potent effector capabilities yet prone to exhaustion due to high PD-1 expression, iterative priming would lead to a continuous replenishment of central memory $\mathrm{T}$ cells with a low PD-1 expression level and potentiate a renewed source of effector cells upon subsequent boosting. It is also quite possible that co-administration of TLR-ligands with boosting peptide would limit the acquisition and expression levels of PD-1 on effector T cells, thus resulting in a prolonged cellular life-span and enhanced function. This model attempts to explain the synergy between priming and boosting vectors at a single epitope level and the dynamic interplay between various pivotal populations of antigen-specific $\mathrm{T}$ cells (such as central and peripheral memory, PD- $1^{\text {low }}$ and PD- ${ }^{\text {high }}$ ) that determines the overall immunity against the intended target (Figure $4 \mathrm{~B})$. Furthermore, it provides a rationale for why a precise sequence of administration of different vectors for priming or boosting the immune response is a crucial pre-requisite for an enhanced specific $\mathrm{T}$ cell response, measured systemically (Figure 4B) or within lymphoid organs (Figure 5).

The finding that the low PD-1 expression profile afforded by DNA vaccination could be reproduced by intra-lymph node immunization with limited amounts of peptide and TLR stimulation sheds light on the mechanism of action of DNA vaccines and their potency as priming agents in terms of: i) the importance of extended yet reduced levels of antigen exposure; and ii) a role for TCR-independent stimulation through TLRs. However, it should be noted that within this model (Figure 4 and 5) DNA vaccines alone have a limited capability to elicit robust immune responses in homologous prime-boost regimens, as supported by experimental clinical observations as well as mechanistic studies [15-17]. Instead, we argue that the use of DNA vaccines for the purpose of priming high quality antigen-specific $\mathrm{CD}^{+} \mathrm{T}$ cell responses is a viable and highly promising strategy. For example, one could envisage alternating the administration of a DNA vaccine with other vectors such as peptides, recombinant proteins, or viruses for the purpose of inducing and periodically replenishing low PD-1-expressing central-memory $\mathrm{T}$ cells and then, through boosting, maintaining a pool of highly functional effector cells. Thus, such heterologous primeboost regimens would ensure the presence of desirable $\mathrm{T}$ cell populations over a longer interval, prevent overall 


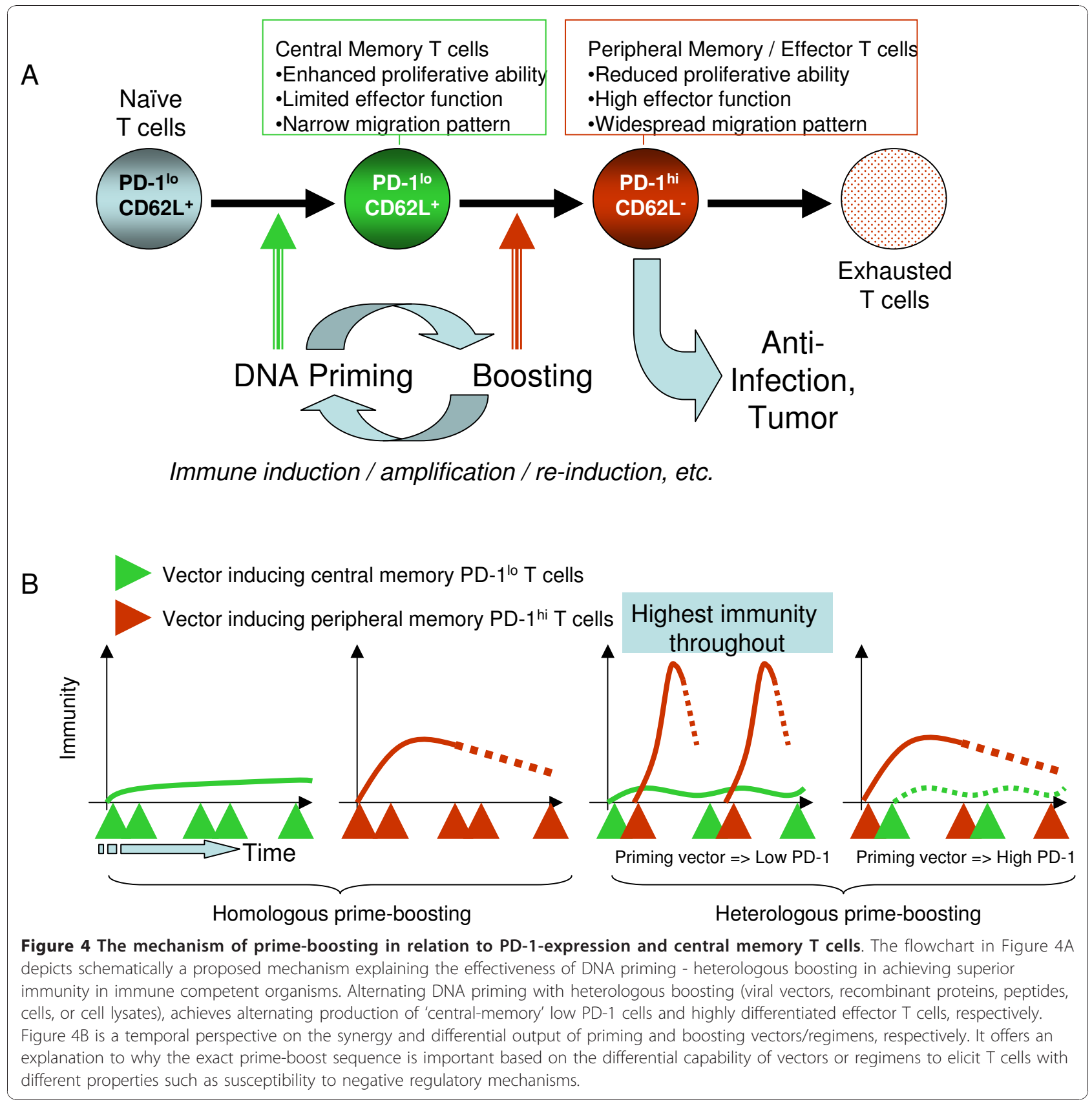

immune exhaustion, and maximize the clinical effect in a therapeutic setting such as cancer, where endogenous antigen exposure alone may not be sufficient to initiate or maintain a clinically relevant immune response.

There may be a more fundamental aspect to these findings related to the basic immune regulatory processes of $\mathrm{CD}^{+} \mathrm{T}$ cell response in general. The conventional paradigm has been that, upon antigen priming or stimulation, responding $\mathrm{T}$ cells go through an unavoidable phase during which they upregulate PD-1 [53]. During the next phase when the antigen exposure subsides, a minor subset of T cells down-regulate PD-1 and become memory cells, while the larger pool of effector cells extinguishes through a range of mechanisms leading to cellular apoptosis. Conversely, if the antigen exposure persists or elevates beyond a certain threshold, the specific $\mathrm{T}$ cells would undergo 'exhaustion' mediated primarily by PD-1, a quite distinctive mechanism of immune regulation [54,55]. In the specific case of HIV, PD-1-induced interleukin-10 production by monocytes impairs $\mathrm{CD} 4^{+} \mathrm{T}$ cell activation, further amplifying the pathogenesis [55]. Instead of supporting 


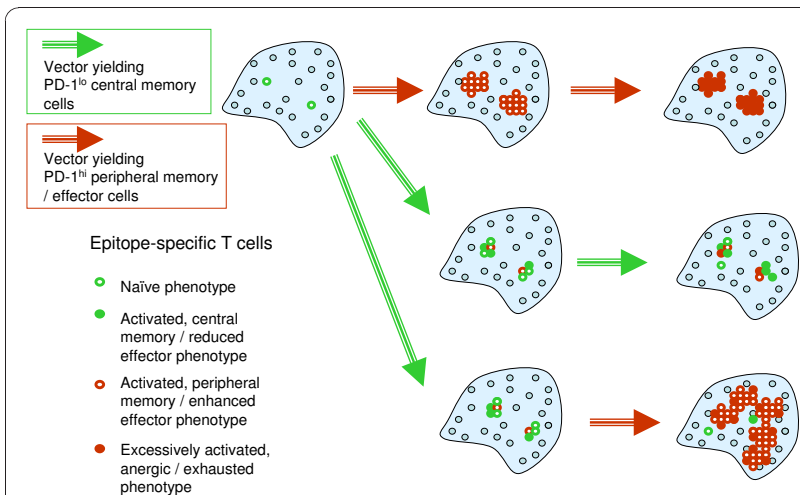

Figure 5 Schematic representation of the kinetics of various subsets of $\mathrm{T}$ cells within secondary lymphoid organs. This is a complementary perspective to that in Figure $4 \mathrm{~B}$, providing a rationale to why a specific sequence of priming and boosting is important to generating an elevated immune response.

this 'serial' differentiation model (with sequential up-regulation and down-regulation of PD-1), our results support a 'branched' differentiation model for $\mathrm{CD}^{+} \mathrm{T}$ cells $[56,57]$. Accordingly, certain immunization regimens or immune threats expose lymphatic organs to continuously low levels of antigen and robust co-stimulation signals, which result in $\mathrm{T}$ cells that fail to up-regulate PD-1 or other co-inhibitory molecules, are less susceptible to negative regulatory mechanisms, and instead are in a prolonged state of 'readiness' (Figure 6). We can only speculate that this mechanism of immune regulation, based on a separate PD- $1^{\text {low }} \mathrm{T}$ cell branch, evolved to provide the immune system with an advantage over highly virulent microbes that easily penetrate the outer layers of innate immune defense.

\section{Optimization of prime-boost vaccines based on PD-1 expression and functional avidity of $T$ cells}

The body of evidence discussed in this review supports three major conclusions. First, a heterologous primeboost vaccine should ideally encompass a priming regimen that results in the induction of specific $\mathrm{T}$ cells co-expressing low levels of inhibitory receptors. Thus, following a heterologous boost (even within a short timeframe), these cells would expand and differentiate into effector cells rather than being subjected to negative regulatory mechanisms. Secondly, emerging data suggests that DNA vaccines have the capability to elicit low PD-1 expressing $\mathrm{CD}^{+} \mathrm{T}$ cells of central-memory phenotype, a process reproduced by repeat intra-lymph node exposure to minute levels of antigen in the presence of robust TLR9 stimulation. Third, this evidence points to a new dimension of immune homeostasis determined by a tight and synchronized control of inhibitory molecule expression by $\mathrm{CD}^{+} \mathrm{T}$ cells during antigen exposure. This facet

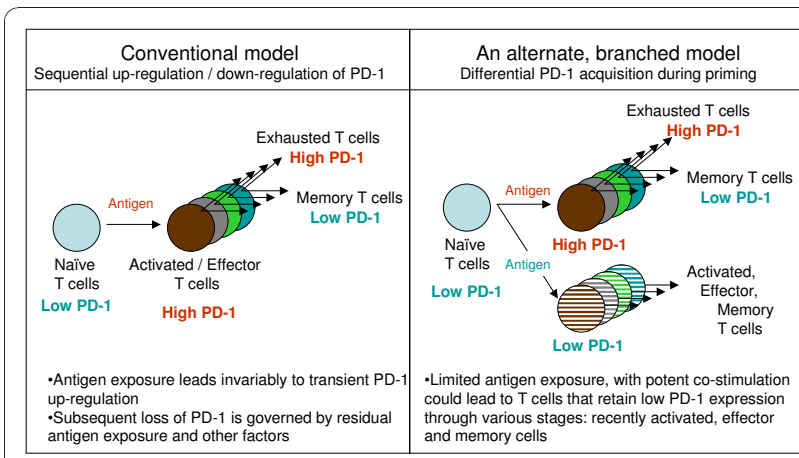

Figure 6 Another dimension to the immune regulation of $\mathrm{CD}^{+}$ T cells based on PD-1 expression. The lack of PD-1 up-regulation during priming may define a separate differentiation lineage. A current model (left side) depicts activation and differentiation of T cells, in relation to PD-1 expression, as a sequential upregulation and downregulation of PD-1, respectively. In this model, activated T cells unavoidably go through a stage in which they are sensitive to PD-1/PD-1L dependent negative regulatory mechanisms. Conversely, in the model depicted on the right side, the acquisition of PD-1 during $T$ cell priming could be limited - depending on the priming regimen - thus yielding $T$ cells that are not as susceptible to negative regulatory mechanisms associated with continuous or repeated antigen exposure. Thus, based on this model - and supported by recent evidence $(42,48)$ - immediate boosting would yield substantially higher immunity as opposed to immune 'exhaustion'. This enables the development of shortened immunization regimens utilizing a heterologous prime-boost strategy.

of immune homeostasis would shape - as a function of antigen exposure and co-stimulation - the delicate balance between long-lived, readily expandable $\mathrm{CD} 8^{+} \mathrm{T}$ cells and short-lived $\mathrm{T}$ cells that are subject to exhaustion or other negative regulatory mechanisms, in a manner fitting the immunological threat.

Key prerequisites for an effective immune response-to control disseminated tumors for example-are not only the sheer numbers of tumor-associated antigen (TAA)specific $\mathrm{T}$ cells but their quality or capability to recognize and eradicate cancerous cells. The latter depends on the functional avidity of the T cells [58] as well as their polyfunctionality [59] in an environment plagued by immune evasion mechanisms [60]. An interesting fact is that the induction of high magnitude immunity, generally requiring exposure to significant antigen doses, may result in a lower proportion of high avidity $\mathrm{T}$ cells $[61,62]$. This is quite important since tumor cells as well as chronically infected cells may display significantly reduced amounts of antigen which are 'invisible' to vaccine-specific $\mathrm{T}$ cells displaying low functional avidity, yet readily quantifiable with current immune monitoring techniques [63].

The interplay between antigen exposure and costimulation, with relevance to the acquisition of PD-1 and preferential induction of high avidity $\mathrm{T}$ cells, is represented in Figure 7. Altogether, this model lays 

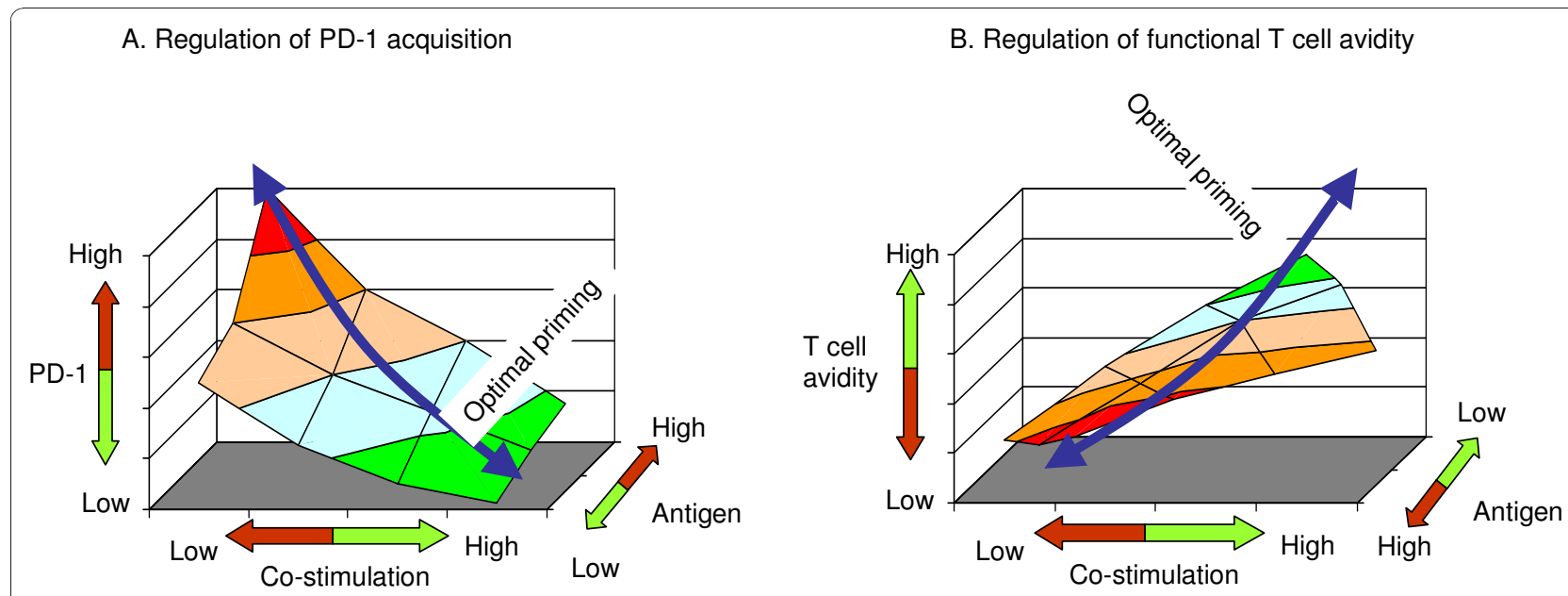

C. Major features of synergistic priming and boosting regimens

\begin{tabular}{|c|c|}
\hline Priming regimen & Boosting regimen \\
\hline $\begin{array}{l}\text { Limited antigen exposure } \\
\text { Robust, optimal co-stimulation }\end{array}$ & $\begin{array}{l}\text { Substantial exposure to antigen } \\
\text { Co-stimulation facultative }\end{array}$ \\
\hline $\begin{array}{l}\text { => Yielding high avidity T cells, with } \\
\text { excellent memory recall features, } \\
\text { restricted migration and refractory to } \\
\text { negative regulatory mechanisms }\end{array}$ & $\begin{array}{l}\text { => Expanding high avidity T cells, with } \\
\text { broad functionality and widespread } \\
\text { migration pattern, yet more susceptible } \\
\text { to negative regulatory mechanisms }\end{array}$ \\
\hline
\end{tabular}

Figure 7 Co-regulation of PD-1 acquisition and functional avidity of T cells during immune priming. A and B show schematically the key parameters controlling two complementary features of T cells resulting from immune priming: PD-1 expression (A) and the functional avidity (B). Effective priming warrants optimal, balanced exposure to TCR-dependent and independent stimuli ("green zone") resulting in T cells with a desired effector profile upon boosting. Please note the inverse relationship between functional avidity and the amount of antigen. The table (bottom) depicts the major, synergistic features of priming and boosting vectors/regimens, as a pre-requisite to designing superior vaccination strategies. The model is based on published research (eg. refs $[40,42,48,59,60]$ ).

out a novel paradigm for designing heterologous prime-boost vaccines and potentially optimizing homologous prime-boost regimens, applicable to difficult and unmet indications such as cancer and chronic viral infections. The core principle of this paradigm is the selection and optimization of the priming vector or regimen, to achieve induction of specific $\mathrm{T}$ cells that meet the following three criteria:

1) have low expression of co-inhibitory receptors (PD-1);

2) display a central memory phenotype;

3) have a high TCR functional avidity.

This new paradigm assumes that the selection of vectors is such that it would not result in a deleterious anti-vector immunity. The priming strategy could then be matched with heterologous vectors that expand and/ or differentiate the primed cells to therapeutically useful effector $\mathrm{T}$ cells or, alternatively, with homologous boosting leading to much higher antigen exposure than during priming. Notably, the latter, which could be a less expensive strategy since it relies only on one vector, is supported by the observation that exposure to gradually higher levels of antigen (starting from minute amounts) over a fairly short interval of just a few days achieved an unexpectedly robust immune response [64], usually only attainable by live virus infection or heterologous prime-boost vaccination. A similar principle could be applied to homologous prime-boost regimens encompassing naked DNA as primer followed by electroporated DNA as a boosting agent [65]. Effective priming may also be achievable through intradermal delivery of DNA as shown in a model of human skin tattooing [66].

In light of the scarcity of antigen-specific immune interventions that achieve clear-cut therapeutic benefits in cancer and chronic infections, there is clearly a need for advanced vaccine approaches that undergo rigorous testing and afford objective, quantifiable clinical responses. The paradigm outlined in this review shifts the focus from the overarching objective of inducing high 
numbers of vaccine-specific lymphocytes to that of generating highly efficacious $\mathrm{T}$ cells that are potent in adverse environments brought about by continuous antigen exposure or non-antigen related immune inhibitory mechanisms. Furthermore, these observations warrant a revision of current immune monitoring approaches in an effort to more accurately measure, predict and optimize the efficacy of active immunotherapies.

\section{Conclusions}

Mounting evidence supports a different model defining the mechanisms of heterologous prime-boost immunization at the epitope level. In summary, effective priming necessitates low PD-1-expressing central memory $\mathrm{T}$ cells and boosting results in their expansion and conversion to effector $\mathrm{T}$ cells equipped with broad migratory and functional capabilities. This mechanism is most likely linked to a new dimension of immune homeostasis with a possible role in ensuring the 'response-readiness' of $\mathrm{CD}^{+} \mathrm{T}$ cells, depending on the nature and magnitude of the immunological threat. Finally, this paradigm suggests a series of valuable criteria to guide the design of new immunization regimens.

\section{Acknowledgements}

We acknowledge the contribution of our collaborators: Mayra Carrillo, Diljeet Joea, Xiping Liu, Uriel Malyankar, Brenna Meisenburg, Robb Pagarigan, Angeline Quach, Darlene Rosario, and Victor Tam for generating some of the key experimental evidence in support of the model put forward in this review.

\section{Authors' contributions}

$A B$ wrote the first draft. $Z Q, R W, M O$, and KAS provided comments and edits for revisions. All authors agreed on the final manuscript.

\section{Competing interests}

$A B, Z Q, R W$ and $M O$ are full time employee receiving salaries from

MannKind Corporation. KAS is a paid consultant of MannKind Corporation.

Received: 11 August 2010 Accepted: 14 December 2010

Published: 14 December 2010

\section{References}

1. Hilleman MR: Vaccines in historic evolution and perspective: a narrative of vaccine discoveries. Vaccine 2000, 18:1436-1447.

2. Schiller JT, Lowy DR: Vaccines to prevent infections by oncoviruses. Annu Rev Microbiol 2010, 64:23-41.

3. Kenter GG, Welters MJ, Valentijn AR, Lowik MJ, Berends-van der Meer DM, Vloon AP, Essahsah F, Fathers LM, Offringa R, Drijfhout JW, Wafelman AR, Oostendorp J, Fleuren GJ, van der Burg SH, Melief CJ: Vaccination against HPV-16 oncoproteins for vulvar intraepithelial neoplasia. N Engl J Med 2010, 363:943-53.

4. Boon T, Szikora JP, De Plaen E, Wölfel T, Van Pel A: Cloning and characterization of genes coding for tum- transplantation antigens. J Autoimmun 1989, 2:s109-114.

5. Morse MA, Whelan M: A year of successful cancer vaccines points to a path forward. Curr Opin Mol Ther 2010, 12:11-13.

6. Mocellin S, Mandruzzato S, Bronte V, Lise M, Nitti D: Part I: Vaccines for solid tumours. The Lancet Oncology 2004, 5:681-9.

7. Mocellin S, Semenzato G, Mandruzzato S, Rossi CR: Part II: Vaccines for haematological malignant disorders. The Lancet Oncology 2004, 5:727-37.
8. Lu S: Heterologous prime-boost vaccination. Curr Opin Immunol 2009, 21:346-351.

9. Bansal GP, Malaspina A, Flores J: Future paths for HIV vaccine research: Exploiting results from recent clinical trials and current scientific advances. Curr Opin Mol Ther 2010, 12:39-46.

10. Benmira S, Bhattacharya V, Schmid ML: An effective HIV vaccine: a combination of humoral and cellular immunity? Curr HIV Res 2010 8:441-9.

11. Wang S, Kennedy JS, West K, Montefiori DC, Coley S, Lawrence J, Shen S, Green S, Rothman AL, Ennis FA, Arthos J, Pal R, Markham P, Lu S: Crosssubtype antibody and cellular immune responses induced by a polyvalent DNA prime-protein boost HIV-1 vaccine in healthy human volunteers. Vaccine 2008, 26:3947-3957.

12. Kent $\mathrm{S}$, De Rose R, Rollman E: Drug evaluation: DNA/MVA prime-boost HIV vaccine. Curr Opin Investig Drugs 2007, 8:159-167.

13. Nayak S, Herzog RW: Progress and prospects: immune responses to viral vectors. Gene Ther 2010, 17:295-304.

14. Truckenmiller ME, Norbury CC: Viral vectors for inducing CD8+ T cell responses. Expert Opin Biol Ther 2004, 4:861-868.

15. Liu MA: Gene-based vaccines: recent developments. Curr Opin Mol Ther 2010, 12:86-93.

16. Lu S: Immunogenicity of DNA vaccines in humans: it takes two to tango. Hum Vaccin 2008, 4:449-452.

17. Bot A, Stan AC, Inaba K, Steinman R, Bona C: Dendritic cells at a DNA vaccination site express the encoded influenza nucleoprotein and prime MHC class I-restricted cytolytic lymphocytes upon adoptive transfer. Int Immunol 2000, 12:825-832.

18. Webster RG, Robinson HL: DNA vaccines: a review of developments. BioDrugs 1997, 8:273-292.

19. Maloy KJ, Erdmann I, Basch V, Sierro S, Kramps TA, Zinkernagel RM, Oehen S, Kündig TM: Intralymphatic immunization enhances DNA vaccination. Proc Natl Acad Sci USA 2001, 98:3299-3303.

20. Weber J, Boswell W, Smith J, Hersh E, Snively J, Diaz M, Miles S, Liu X, Obrocea M, Qiu Z, Bot A: Phase 1 trial of intranodal injection of a MelanA/MART-1 DNA plasmid vaccine in patients with stage IV melanoma. J Immunother 2008, 31:215-223.

21. Bodles-Brakhop AM, Heller R, Draghia-Akli R: Electroporation for the delivery of DNA-based vaccines and immunotherapeutics: current clinical developments. Mol Ther 2009, 17:585-592.

22. Wang S, Pal R, Mascola JR, Chou TH, Mboudjeka I, Shen S, Liu Q, Whitney S, Keen T, Nair BC, Kalyanaraman VS, Markham P, Lu S: Polyvalent HIV-1 Env vaccine formulations delivered by the DNA priming plus protein boosting approach are effective in generating neutralizing antibodies against primary human immunodeficiency virus type 1 isolates from subtypes A, B, C, D and E. Virology 2006, 350:34-47.

23. Lu Y, Ouyang K, Fang J, Zhang H, Wu G, Ma Y, Zhang Y, Hu X, Jin L, Cao R, Fan $H, L i$, Liu J: Improved efficacy of DNA vaccination against prostate carcinoma by boosting with recombinant protein vaccine and by introduction of a novel adjuvant epitope. Vaccine 2009, 27:5411-5418.

24. Bot A, Bot S, Garcia-Sastre A, Bona C: DNA immunization of newborn mice with a plasmid-expressing nucleoprotein of influenza virus. Viral Immunol 1996, 9:207-210.

25. Skinner MA, Wedlock DN, de Lisle GW, Cooke MM, Tascon RE, Ferraz JC, Lowrie DB, Vordermeier HM, Hewinson RG, Buddle BM: The order of prime-boost vaccination of neonatal calves with Mycobacterium bovis BCG and a DNA vaccine encoding mycobacterial proteins Hsp65, Hsp70, and Apa is not critical for enhancing protection against bovine tuberculosis. Infect Immun 2005, 73:4441-4444.

26. Amara RR, Villinger F, Altman JD, Lydy SL, O'Neil SP, Staprans SI, Montefiori DC, Xu Y, Herndon JG, Wyatt LS, Candido MA, Kozyr NL, Earl PL, Smith JM, Ma HL, Grimm BD, Hulsey ML, Miller J, McClure HM, McNicholl JM, Moss B, Robinson HL: Control of a mucosal challenge and prevention of AIDS by a multiprotein DNA/MVA vaccine. Science 2001, 292:69-74

27. Kent SJ, Zhao A, Best SJ, Chandler JD, Boyle DB, Ramshaw IA: Enhanced T-cell immunogenicity and protective efficacy of a human immunodeficiency virus type 1 vaccine regimen consisting of consecutive priming with DNA and boosting with recombinant fowlpox virus. J Virol 1998, 72:10180-10188. 
28. Shiver JW, Fu TM, Chen L, Casimiro DR, Davies ME, Evans RK, Zhang ZQ, Simon AJ, Trigona WL, Dubey SA, Huang L, Harris VA, Long RS, Liang X, Handt L, Schleif WA, Zhu L, Freed DC, Persaud NV, Guan L, Punt KS, Tang A, Chen M, Wilson KA, Collins KB, Heidecker GJ, Fernandez VR, Perry HC, Joyce JG, Grimm KM, Cook JC, Keller PM, Kresock DS, Mach H, Troutman RD, Isopi LA, Williams DM, Xu Z, Bohannon KE, Volkin DB, Montefiori DC, Miura A, Krivulka GR, Lifton MA, Kuroda MJ, Schmitz JE, Letvin NL, Caulfield MJ, Bett AJ, Youil R, Kaslow DC, Emini EA: Replicationincompetent adenoviral vaccine vector elicits effective antiimmunodeficiency-virus immunity. Nature 2002, 415:331-335.

29. Meng WS, Butterfield LH, Ribas A, Dissette VB, Heller JB, Miranda GA, Glaspy JA, McBride WH, Economou JS: alpha-Fetoprotein-specific tumor immunity induced by plasmid prime-adenovirus boost genetic vaccination. Cancer Res 2001, 61:8782-8786.

30. Egan MA, Chong SY, Megati S, Montefiori DC, Rose NF, Boyer JD, Sidhu MK, Quiroz J, Rosati M, Schadeck EB, Pavlakis GN, Weiner DB, Rose JK, Israel ZR Udem SA, Eldridge JH: Priming with plasmid DNAs expressing interleukin-12 and simian immunodeficiency virus gag enhances the immunogenicity and efficacy of an experimental AIDS vaccine based on recombinant vesicular stomatitis virus. AIDS Res Hum Retroviruses 2005, 21:629-643.

31. Biswas S, Reddy GS, Srinivasan VA, Rangarajan PN: Preexposure efficacy of a novel combination DNA and inactivated rabies virus vaccine. Hum Gene Ther 2001, 12:1917-1922.

32. Wang S, Parker C, Taaffe J, Solórzano A, García-Sastre A, Lu S: Heterologous HA DNA vaccine prime-inactivated influenza vaccine boost is more effective than using DNA or inactivated vaccine alone in eliciting antibody responses against $\mathrm{H} 1$ or $\mathrm{H} 3$ serotype influenza viruses. Vaccine 2008, 26:3626-3633.

33. Bansal A, Jackson B, West K, Wang S, Lu S, Kennedy JS, Goepfert PA: Multifunctional T-cell characteristics induced by a polyvalent DNA prime/protein boost human immunodeficiency virus type 1 vaccine regimen given to healthy adults are dependent on the route and dose of administration. J Virol 2008, 82:6458-6469.

34. Harari A, Bart PA, Stöhr W, Tapia G, Garcia M, Medjitna-Rais E, Burnet S, Cellerai C, Erlwein O, Barber T, Moog C, Liljestrom P, Wagner R, Wolf H, Kraehenbuhl JP, Esteban M, Heeney J, Frachette MJ, Tartaglia J, McCormack S, Babiker A, Weber J, Pantaleo G: An HIV-1 clade C DNA prime, NYVAC boost vaccine regimen induces reliable, polyfunctional, and long-lasting T cell responses. J Exp Med 2008, 205:63-77.

35. Todorova K, Ignatova I, Tchakarov S, Altankova I, Zoubak S, Kyurkchiev S, Mincheff M: Humoral immune response in prostate cancer patients after immunization with gene-based vaccines that encode for a protein that is proteasomally degraded. Cancer Immun 2005, 5:1.

36. Dangoor A, Lorigan P, Keilholz U, Schadendorf D, Harris A, Ottensmeier C, Smyth J, Hoffmann K, Anderson R, Cripps M, Schneider J, Hawkins R: Clinical and immunological responses in metastatic melanoma patients vaccinated with a high-dose poly-epitope vaccine. Cancer Immunol Immunother 2010, 59:863-873.

37. McConkey SJ, Reece WH, Moorthy VS, Webster D, Dunachie S, Butcher G, Vuola JM, Blanchard TJ, Gothard P, Watkins K, Hannan CM, Everaere S, Brown K, Kester KE, Cummings J, Williams J, Heppner DG, Pathan A, Flanagan K, Arulanantham N, Roberts MT, Roy M, Smith GL, Schneider J, Peto T, Sinden RE, Gilbert SC, Hill AV: Enhanced T-cell immunogenicity of plasmid DNA vaccines boosted by recombinant modified vaccinia virus Ankara in humans. Nat Med 2003, 9:729-735.

38. Tacken PJ, de Vries IJ, Torensma R, Figdor CG: Dendritic-cell immunotherapy: from ex vivo loading to in vivo targeting. Nat Rev Immunol 2007, 7:790-802

39. Vuola JM, Keating S, Webster DP, Berthoud T, Dunachie S, Gilbert SC, Hill AV: Differential immunogenicity of various heterologous prime-boost vaccine regimens using DNA and viral vectors in healthy volunteers. J Immunol 2005, 174:449-55.

40. Smith KA, Tam VL, Wong RM, Pagarigan RR, Meisenburg BL, Joea DK, Liu X, Sanders C, Diamond D, Kündig TM, Qiu Z, Bot A: Enhancing DNA vaccination by sequential injection of lymph nodes with plasmid vectors and peptides. Vaccine 2009, 27:2603-2615.

41. von Beust BR, Johansen P, Smith KA, Bot A, Storni T, Kündig TM: Improving the therapeutic index of $\mathrm{CpG}$ oligodeoxynucleotides by intralymphatic administration. Eur J Immunol 2005, 35:1869-1876.
42. Smith KA, Qiu Z, Wong R, Tam VL, Tam BL, Joea DK, Quach A, Liu X, Pold M, Malyankar UM, Bot A: Multivalent immunity targeting tumor associated antigens by intra-lymph node DNA-prime, peptide boost vaccination. Cancer Gene Therapy 2010

43. Halwani R, Boyer JD, Yassine-Diab B, Haddad EK, Robinson TM, Kumar S, Parkinson R, Wu L, Sidhu MK, Phillipson-Weiner R, Pavlakis GN, Felber BK, Lewis MG, Shen A, Siliciano RF, Weiner DB, Sekaly RP: Therapeutic vaccination with simian immunodeficiency virus (SIV)-DNA + IL-12 or IL-15 induces distinct CD8 memory subsets in SIV-infected macaques. J Immunol 2008, 180:7969-79.

44. Velu V, Kannanganat S, Ibegbu C, Chennareddi L, Villinger F, Freeman GJ, Ahmed R, Amara RR: Elevated expression levels of inhibitory receptor programmed death 1 on simian immunodeficiency virus-specific CD8 T cells during chronic infection but not after vaccination. J Virol 2007, 81:5819-28.

45. Ishida Y, Agata Y, Shibahara K, Honjo T: Induced expression of PD-1, a novel member of the immunoglobulin gene superfamily, upon programmed cell death. EMBO J 1992, 11:3887-3895.

46. Grosso JF, Kelleher CC, Harris TJ, Maris CH, Hipkiss EL, De Marzo A Anders R, Netto G, Getnet D, Bruno TC, Goldberg MV, Pardoll DM, Drake CG: LAG-3 regulates CD8+ T cell accumulation and effector function in murine self- and tumor-tolerance systems. J Clin Invest 2007, 117:3383-3392.

47. Peggs KS, Quezada SA, Korman AJ, Allison JP: Principles and use of antiCTLA4 antibody in human cancer immunotherapy. Curr Opin Immunol 2006, 18:206-213.

48. Wong RM, Smith KA, Tam VL, Pagarigan RR, Meisenburg BL, Quach AM, Carrillo MA, Qiu Z, Bot Al: TLR-9 signaling and TCR stimulation coregulate CD8(+) T cell-associated PD-1 expression. Immunol Lett 2009, 127:60-67.

49. Schwarz K, Storni T, Manolova V, Didierlaurent A, Sirard JC, Röthlisberger P, Bachmann MF: Role of Toll-like receptors in costimulating cytotoxic T cell responses. Eur J Immunol 2003, 33:1465-70.

50. Akira S, Hemmi H: Recognition of pathogen-associated molecular patterns by TLR family. Immuno Lett 2003, 85:85-95.

51. Wang L, Smith D, Bot S, Dellamary L, Bloom A, Bot A: Noncoding RNA danger motifs bridge innate and adaptive immunity and are potent adjuvants for vaccination. J Clin Invest 2002, 110:1175-84.

52. Keir ME, Freeman GJ, Sharpe AH: PD-1 regulates self-reactive CD8+ T cell responses to antigen in lymph nodes and tissues. J Immunol 2007, 179:5064-70.

53. Grosso JF, Goldberg MV, Getnet D, Bruno TC, Yen HR, Pyle K, Hipkiss E, Vignali DA, Pardoll DM, Drake CG: Functionally distinct LAG-3 and PD-1 subsets on activated and chronically stimulated CD8 T cells. J Immunol 2009, 182:6659-6669.

54. Riley JL: PD-1 signaling in primary T cells. Immunol Rev 2009, 229:114-125.

55. Said EA, Dupuy FP, Trautmann L, Zhang Y, Shi Y, El-Far M, Hill BJ, Noto A, Ancuta P, Peretz Y, Fonseca SG, Van Grevenynghe J, Boulassel MR, Bruneau J, Shoukry NH, Routy JP, Douek DC, Haddad EK, Sekaly RP: Programmed death-1-induced interleukin-10 production by monocytes impairs CD4+ T cell activation during HIV infection. Nat Med 2010, 16:452-459.

56. Laouar A, Manocha M, Haridas V, Manjunath N: Concurrent generation of effector and central memory CD8 T cells during vaccinia virus infection. PLOS ONE 2008, 3:e4089.

57. Huster KM, Busch V, Schiemann M, Linkemann K, Kerksiek KM, Wagner $\mathrm{H}$, Busch DH: Selective expression of IL-7 receptor on memory T cells identifies early CD40L-dependent generation of distinct CD8+ memory $T$ cell subsets. PNAS USA 2004, 101:5610-5.

58. Alexander-Miller MA: High-avidity CD8+ T cells: optimal soldiers in the war against viruses and tumors. Immunol Res 2005, 31:13-24.

59. Almeida JR, Price DA, Papagno L, Arkoub ZA, Sauce D, Bornstein E, Asher TE, Samri A, Schnuriger A, Theodorou I, Costagliola D, Rouzioux C, Agut H, Marcelin AG, Douek D, Autran B, Appay V: Superior control of HIV1 replication by $C D 8+T$ cells is reflected by their avidity, polyfunctionality, and clonal turnover. J Exp Med 2007, 204:2473-2485.

60. Lasaro MO, Ertl HC: Targeting inhibitory pathways in cancer immunotherapy. Curr Opin Immunol 2010, 22:385-90.

61. Bullock TN, Mullins DW, Engelhard VH: Antigen density presented by dendritic cells in vivo differentially affects the number and avidity of 
primary, memory, and recall CD8+ T cells. J Immunol 2003,

170:1822-1829.

62. Bullock TN, Colella TA, Engelhard VH : The density of peptides displayed by dendritic cells affects immune responses to human tyrosinase and gp100 in HLA-A2 transgenic mice. J Immunol 2000, 164:2354-2361.

63. Lin Y, Gallardo HF, Ku GY, Li H, Manukian G, Rasalan TS, Xu Y, Terzulli SL, Old L, Allison JP, Houghton AN, Wolchok JD, Yuan J: Optimization and validation of a robust human T-cell culture method for monitoring phenotypic and polyfunctional antigen-specific CD4 and CD8 T-cell responses. Cytotherapy 2009, 11:1-11.

64. Johansen P, Storni T, Rettig L, Qiu Z, Der-Sarkissian A, Smith KA

Manolova V, Lang KS, Senti G, Müllhaupt B, Gerlach T, Speck RF, Bot A, Kündig TM: Antigen kinetics determines immune reactivity. Proc Natl Acad Sci USA 2008, 105:5189-5194.

65. Buchan S, Grønevik E, Mathiesen I, King CA, Stevenson FK, Rice J: Electroporation as a "prime/boost" strategy for naked DNA vaccination against a tumor antigen. J Immunol 2005, 174:6292-6298.

66. van den Berg JH, Nuijen B, Beijnen JH, Vincent A, Tinteren H, Kluge J, Woerdeman LA, Hennink WE, Storm G, Schumacher TN, Haanen JB: Optimization of intradermal vaccination by DNA tattooing in human skin. Hum gene ther 2009, 20:181-9.

doi:10.1186/1479-5876-8-132

Cite this article as: Bot et al:: Programmed cell death-1 (PD-1) at the heart of heterologous prime-boost vaccines and regulation of $\mathrm{CD} 8^{+}$ T cell immunity. Journal of Translational Medicine 2010 8:132.

\section{Submit your next manuscript to BioMed Central} and take full advantage of:

- Convenient online submission

- Thorough peer review

- No space constraints or color figure charges

- Immediate publication on acceptance

- Inclusion in PubMed, CAS, Scopus and Google Scholar

- Research which is freely available for redistribution

Submit your manuscript at www.biomedcentral.com/submit 